\title{
Urinary nitrate excretion is increased in patients with rheumatoid arthritis and reduced by prednisolone
}

\author{
Dirk O Stichtenoth, Joachim Fauler, Henning Zeidler, Jürgen C Frölich
}

\begin{abstract}
Objectives-To determine daily production of nitric oxide (NO) measured as urinary nitrate excretion, and the effect of prednisolone in patients with rheumatoid arthritis (RA).

Methods-Twenty four hour urinary nitrate was measured by gas chromatography in 10 patients with $R A$, before and two to four weeks after commencement of prednisolone $0.5 \mathrm{mg} / \mathrm{kg}$ body weight, and in 18 healthy controls.

Results-Before the start of prednisolone treatment the urinary nitrate excretion in patients with $R A$ was $2 \cdot 7$-fold greater $(p<0.001)$ than that in healthy volunteers. After prednisolone it decreased significantly, by $28 \%$, at which time inflammatory activity (as indicated by $C$ reactive protein, erythrocyte sedimentation rate, joint count, and early morning stiffiness) was also reduced considerably. Despite this decrease, the urinary nitrate excretion in patients with $R A$ remained twice that in the control group $(p<0.05)$. Conclusion-Our data suggest that the endogenous production of NO is enhanced in patients with RA. Furthermore, the results indicate that, in parallel with suppression of inflammation, this increased NO synthesis could be reduced by prednisolone treatment.
\end{abstract}

(Ann Rheum Dis 1995; 54: 820-824)

Nitric oxide (NO), synthesised by the inducible form of NO synthase, has been implicated as an important mediator of specific and non-specific immune responses. ${ }^{1}$ Cytokines such as tumour necrosis factor $\alpha$, interferon gamma or interleukin-1, which are involved in the pathogenesis of rheumatoid arthritis (RA), ${ }^{2}$ were shown to induce this isoform of NO synthase. ${ }^{3}$ After induction, monocytes, ${ }^{4}$ neutrophils, ${ }^{5}$ chondrocytes, ${ }^{6}$ synoviocytes, ${ }^{7}$ and many other human cells are able to synthesise large amounts of NO. The NO produced exerts cytotoxic effects via inhibition of iron containing enzymes, interference with deoxyribonucleic acid, and reaction with superoxide anion to form peroxynitrite, which can decompose to highly reactive hydroxyl radicals. ${ }^{8}$ NO is also produced by two constitutive forms of NO synthase. ${ }^{9}$ These isoforms in endothelial cells, neuronal cells, and platelets generate small amounts of $\mathrm{NO}$, responsible for regulation of vascular tone, ${ }^{10}$ platelet aggregation ${ }^{11}$ and neuronal signal transduction; ${ }^{12}$ these actions are mediated by activation of soluble guanylate cyclase, followed by increased concentrations of cyclic guanosine monophosphate. ${ }^{13}$

Little is known about the importance of the NO pathway in inflammatory joint diseases. Studies in experimental adjuvant arthritis ${ }^{14} 15$ and streptococcal cell wall induced arthritis ${ }^{16}$ suggested increased endogenous NO synthesis in inflammatory joint diseases. In man, Farrell et $a l^{17}$ reported increased concentrations of nitrite, a metabolite of $\mathrm{NO}$, in serum and synovial fluid of patients with RA. NO itself is difficult to measure directly in vivo, because it is readily oxidised to nitrite and nitrate ${ }^{18}$ which are excreted rapidly into the urine. This endogenous nitrate synthesis explains the finding, made before discovery of the NO pathway, that people taking diets low in nitrate excrete four fold more nitrate in the urine than the amount ingested in their diet. ${ }^{19}$ Furthermore, only $40-60 \%$ of the ingested nitrate appeared in urine, ${ }^{19} 20$ which helps to explain why people taking a diet high in nitrate excrete less nitrate in the urine than they ingest. ${ }^{19}$ To summarise: in the absence of excess dietary nitrate intake, the major source of urinary nitrate is endogenously synthesised NO. ${ }^{21}{ }^{22} \mathrm{NO}$ synthase activity can therefore be reliably and noninvasively assessed by measurement of urinary nitrate excretion. ${ }^{23}$ In the present study we determined urinary nitrate excretion and the effect of prednisolone in patients with RA.

\section{Patients and methods}

PATIENTS

Ten patients with RA as defined by the revised American Rheumatism Association criteria of $1987^{24}$ were studied. For entry to the study they were required to have systemic disease activity, as indicated by $C$ reactive protein $(C R P)>15 \mathrm{mg} / \mathrm{l}$, and clinical disease activity (more than five joints involved, early morning stiffness of more than one hour duration). Exclusion criteria were inflammatory diseases other than RA, and treatment with prednisolone $>10 \mathrm{mg} /$ day. At the time of enrolment in the study, the patients had high disease activity (mean CRP 71 (SD) $61 \mathrm{mg} / \mathrm{l}$, erythrocyte sedimentation rate (ESR) 62 (28) $\mathrm{mm} / 1 \mathrm{st} \mathrm{h}$, joint count 20 (6), and early morning stiffness $4(2) \mathrm{h}$ ). Tables 1 and 2 summarise the epidemiological, drug treatment, clinical, and laboratory data of each patient. A control group comprised 18 healthy volunteers (house staff and honorary house 
Table 1 Epidemiological and drug treatment data of patients with $R A$

\begin{tabular}{|c|c|c|c|c|c|}
\hline Patient & $\begin{array}{l}\text { Age (yr) } \\
\text { gender }\end{array}$ & $\begin{array}{l}\text { Disease } \\
\text { duration (yr) }\end{array}$ & $\begin{array}{l}\text { Erosive arthritis/ } \\
\text { rheumatoid factor }\end{array}$ & $\begin{array}{l}\text { Antiphlogistic drugs before } \\
\text { prednisolone } 0.5 \mathrm{mg} / \mathrm{kg} \text { body wt }\end{array}$ & Disease modifying drugs \\
\hline 1 & $68 / F$ & $1 \cdot 0$ & No/positive & Etofenamate $1 \mathrm{~g} /$ day & None \\
\hline 2 & $64 / \mathrm{M}$ & $0 \cdot 5$ & No/negative & Etofenamate $1 \mathrm{~g} /$ day & None \\
\hline 3 & $46 / F$ & 15 & Yes/positive & Etofenamate $1 \mathrm{~g} /$ day & None \\
\hline 4 & $44 / M$ & $1 \cdot 2$ & Yes/positive & $\begin{array}{l}\text { Prednisolone } 7.5 \mathrm{mg} / \mathrm{day} \text { and } \\
\text { indomethacin } 200 \mathrm{mg} / \text { day }\end{array}$ & None \\
\hline 5 & $70 / \mathrm{M}$ & $4 \cdot 0$ & Yes/positive & Prednisolone $7.5 \mathrm{mg} /$ day & Sulphasalazine $1.5 \mathrm{~g} /$ day \\
\hline 6 & $72 / \mathrm{M}$ & $0 \cdot 8$ & No/positive & Prednisolone $7.5 \mathrm{mg} /$ day & Sulphasalazine $2 \mathrm{~g} / \mathrm{day}$ \\
\hline 7 & $75 / \mathrm{F}$ & $0 \cdot 3$ & No/negative & None & None \\
\hline 8 & $49 / \mathrm{F}$ & 15 & Yes/positive & Diclofenac $100 \mathrm{mg} /$ day & Methotrexate $10 \mathrm{mg} /$ week \\
\hline 9 & $64 / F$ & $4 \cdot 0$ & Yes/positive & Diclofenac $100 \mathrm{mg} /$ day & None \\
\hline 10 & $75 / \mathrm{F}$ & $2 \cdot 0$ & Yes/positive & $\begin{array}{l}\text { Prednisolone } 10 \mathrm{mg} / \text { day and } \\
\text { diclofenac } 100 \mathrm{mg} / \text { day }\end{array}$ & None \\
\hline Mean (SD) & $63(12)$ & $4 \cdot 4(5 \cdot 8)$ & - & - & - \\
\hline
\end{tabular}

staff) comparable in age (67 (6) years, range 54-75) and gender (12 female, six male).

\section{STUDY PROCEDURE}

All patients gave their informed consent to urine collection for our study; treatment and evaluation of parameters of disease activity were performed according to standard clinical procedures by the resident of the rheumatology ward and were not influenced by our study. Twenty four hour collections of urine for determination of urinary nitrate excretion were collected twice: first, before the start of antiinflammatory therapy with prednisolone, when the patients had high inflammatory activity (see above and table 2), and second, two to four weeks after the start of treatment with prednisolone $0.5 \mathrm{mg} / \mathrm{kg}$ body weight, when the patients showed both biochemical and clinical improvement: CRP 6 (5) mg/l, ESR 32 (17) $\mathrm{mm} / 1$ st $\mathrm{h}(\mathrm{p}<0.05 \mathrm{each}) ;$ joint count 8 (4), early morning stiffness 1 ( 1 ) $h(p<0.001$ each) (for individual patients values, see table 2). When prednisolone treatment was initiated, intake of NSAID was discontinued; treatment with disease modifying drugs remained unchanged.

\section{DIETARY NITRITE/NITRATE INTAKE}

The study groups were not subjected to a standardised diet, but subjects having excess dietary intake of nitrite or nitrate were excluded. We asked patients and controls to restrict their intake of foods containing high amounts of nitrite/nitrate, for example pickled meat, beetroot, spinach, radish, lettuce, or chinese cabbage, and checked the menu plan of our hospital for those foods. Under these conditions the daily nitrite intake is below

Table 2 Parameters of disease activity of patients with $R A$ before and two to four weeks after start of treatment with prednisolone $0.5 \mathrm{mg} / \mathrm{kg}$ body weight

\begin{tabular}{|c|c|c|c|c|c|c|c|c|}
\hline \multirow[t]{2}{*}{ Patient } & \multicolumn{2}{|c|}{$C R P(m g / l)$} & \multicolumn{2}{|c|}{$E S R(m m / 1 s t h)$} & \multicolumn{2}{|c|}{ foint count } & \multicolumn{2}{|c|}{$E M S(h)$} \\
\hline & Before & After & Before & After & Before & After & Before & After \\
\hline 1 & 225 & 2 & 120 & 27 & 23 & 8 & $6 \cdot 0$ & 0.5 \\
\hline 2 & 113 & 2 & 50 & 10 & 16 & 9 & $7 \cdot 0$ & $1 \cdot 0$ \\
\hline 3 & 63 & 15 & 50 & 25 & 18 & 15 & 3.0 & 3.0 \\
\hline 4 & 16 & 2 & 80 & 51 & 26 & 7 & $5 \cdot 0$ & $1 \cdot 0$ \\
\hline 5 & 62 & 11 & 64 & 44 & 18 & 3 & $2 \cdot 0$ & $0 \cdot 1$ \\
\hline 6 & 15 & 2 & 34 & 23 & 25 & 11 & $5 \cdot 0$ & $1 \cdot 0$ \\
\hline 7 & 50 & 9 & 30 & 9 & 28 & 12 & $4 \cdot 0$ & 0.5 \\
\hline 8 & 71 & 2 & 83 & 41 & 16 & 8 & $3 \cdot 0$ & 0.5 \\
\hline 9 & 55 & 4 & 40 & 32 & 19 & 7 & $2 \cdot 0$ & $0 \cdot 1$ \\
\hline 10 & 39 & 10 & 72 & 60 & 9 & 1 & $4 \cdot 0$ & $0 \cdot 2$ \\
\hline Mean (SD) & $71(61)$ & $6(5)$ & $62(28)$ & $32(17)$ & $20(6)$ & $8(4)$ & $4(2)$ & $1(1)$ \\
\hline
\end{tabular}

$\mathrm{CRP}=\mathrm{C}$ reactive protein; $\mathrm{ESR}=$ erythrocyte sedimentation rate; $\mathrm{EMS}=$ early morning stiffness.
$0.07 \mathrm{mmol}$ and daily nitrate intake in the range $0 \cdot 7-1.2 \mathrm{mmol} .^{25} 26$ Vegetarians were excluded from our study, because their dietary intake of nitrite or nitrate is up to 10 -fold greater than these values. ${ }^{26}$ The nitrite/nitrate concentrations in local piped water supplies were less than $0.01 \mathrm{mmol} / 1$ and $0.1 \mathrm{mmol} / 1$, respectively, so this water did not contribute significantly to nitrite/nitrate intake of our study patients and controls.

\section{MEASUREMENT OF NITRATE}

Urinary nitrate was determined by a gas chromatographic method based on a reaction of nitrate with trimethoxybenzene to form trimethoxynitrobenzene. Fifty microlitre aliquots of urine were diluted with $50 \mu \mathrm{l}$ of double distilled water and treated with $300 \mu \mathrm{l}$ of silver sulphate solution $(100 \mathrm{mg} / \mathrm{ml})$ for chloride precipitation. After centrifugation for five minutes at $8000 \mathrm{~g}, 300 \mu \mathrm{l}$ aliquots of the supernatant were mixed with $300 \mu$ l of concentrated sulphuric acid, $20 \mu l$ of trimethoxybenzene in acetone $(1 \mathrm{mg} / \mathrm{ml})$, and $10 \mu \mathrm{l}$ of dimethoxynitrobenzene in acetone $(250 \mathrm{ng} / \mu \mathrm{l})$ as internal standard. After incubation for 10 minutes at $60^{\circ} \mathrm{C}$, the generated nitroaromatics were extracted with $800 \mu$ l of toluene. The toluene layer was drawn off and shaken with 2 $\mathrm{ml}$ of a $4 \mathrm{~mol} / \mathrm{l}$ aqueous sodium hydroxide solution. Subsequently, $100 \mu \mathrm{l}$ of the toluene phase was diluted with $900 \mu l$ of toluene for gas chromatographic analysis. Analysis was performed on a Carlo Erba gas chromatograph model HRGC5160 (Fisons Instruments, Mainz, Germany) equipped with an A200S autosampler and an ECD HT40 electron capture detector. An OV1701 fused silica capillary column (Machery and Nagel, Düren, Germany) was used for chromatographic separation. Helium $(75 \mathrm{kPa})$ was applied as carrier gas and nitrogen $(150 \mathrm{kPa})$ as make up gas. Oven temperature was held at $150^{\circ} \mathrm{C}$ for two minutes then increased to $280^{\circ} \mathrm{C}$ at a rate of $40^{\circ} \mathrm{C} / \mathrm{min}$ and held at $280^{\circ} \mathrm{C}$ for two minutes. The intra- and interassay coefficients of variation were less than $3.5 \%$, and the limit of detection of the method was nitrate $5 \cdot 2$ $\mathrm{nmol} / \mathrm{ml}$. The method was validated by a gas chromatography/tandem mass spectrometry assay $^{27}$ and showed a correlation of $r=0.91$, $\mathrm{n}=15$, within the range of urinary nitrate concentrations. Urinary creatinine was determined spectrophotometrically using the alkaline picric acid method in an automatic 


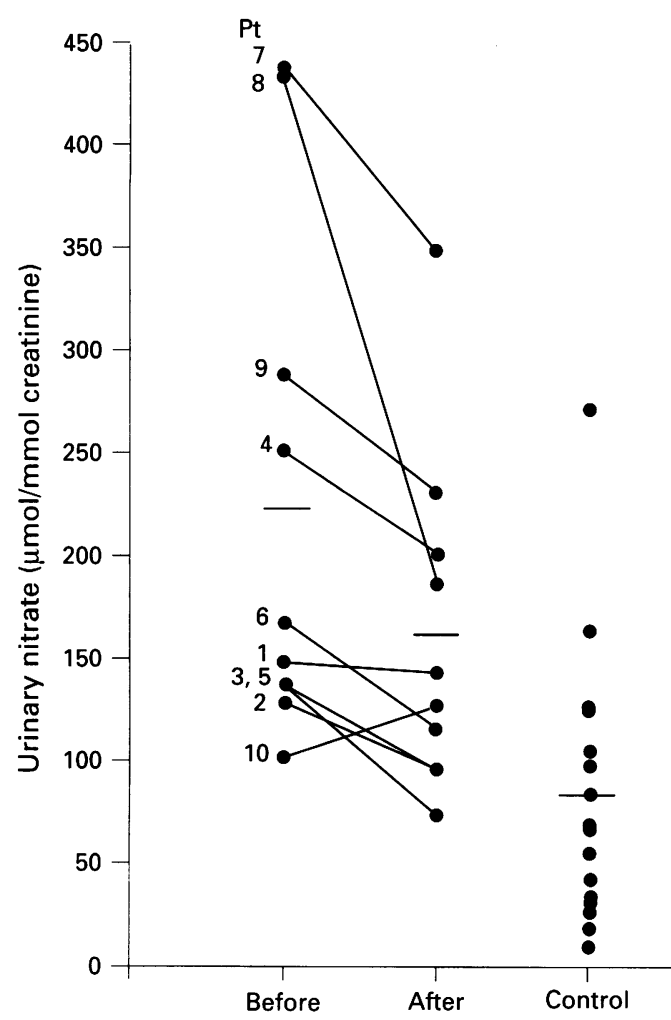

Urinary nitrate excretion of patients with $R A$ before and after start of treatment with prednisolone $0.5 \mathrm{mg} / \mathrm{kg}$ body weight, and of healthy volunteers as control.

Patient numbers $(P t)$ are the same as in tables 1-3.

Horizontal bars represent mean values. Significant

differences: $p<0.001$ for patients before $\mathrm{v}$ control; $p<0.05$ for patients after $\mathrm{v}$ control and for patients before $\mathrm{v}$ patients after.

analyser (Beckman, Galway, Ireland). The urinary excretion rates of nitrate were corrected by creatinine excretion according to the formula: urinary nitrate $(\mu \mathrm{mol} / \mathrm{l})$ :urinary creatinine $(\mathrm{mmol} / \mathrm{l})=$ urinary nitrate $(\mu \mathrm{mol} /$ mmol creatinine).

\section{MEASUREMENT OF CRP AND ESR}

Serum concentrations of CRP were determined by nephelometry in an automatic analyser (Behring, Marburg, Germany). Normal CRP values are $<6 \mathrm{mg} / \mathrm{l}$.

ESR was assessed by the method of Westergren. Normal values for the first hour are: men younger than 50 years $<15 \mathrm{~mm}$; women younger than 50 years $<20 \mathrm{~mm}$; men older than 50 years $<20 \mathrm{~mm}$, women older than 50 years $<30 \mathrm{~mm}$.
DETERMINATION OF JOINT COUNT AND EARLY MORNING STIFFNESS

Joint count was determined by a quantitative articular index similar to the 28 joint index described by Fuchs $e t a l^{28}$ in addition to this 28 joint index we included 10 metatarsophalangeal and 10 proximal interphalangeal joints of the toes- 48 joints in all.

Early morning stiffness was evaluated with the question: 'How long does your morning stiffness last from the time you wake up?' The values were recorded in hours.

\section{STATISTICS}

Data are expressed as mean (SD). Statistical significance of differences was determined by Student's two tailed unpaired $t$ test (patient group versus control) and by the two tailed paired $t$ test (patient group before versus after prednisolone treatment). Statistical analysis of the correlation data was performed using the unpaired $t$ test. $\mathrm{p}<0.05$ was considered significant.

\section{Results}

The figure shows the results of the measurement of urinary nitrate excretion, and table 3 shows the urinary nitrate excretion rates before correction for creatinine. Before the start of prednisolone treatment, the urinary nitrate excretion in patients with RA $(223$ (126) $\mu \mathrm{mol} /$ mmol creatinine) was $2 \cdot 7$-fold greater than that in healthy volunteers (83 (63) $\mu \mathrm{mol} / \mathrm{mmol}$ creatinine $)(p<0.001)$. It decreased significantly $(\mathrm{p}<0.05)$, to $162(83) \mu \mathrm{mol} / \mathrm{mmol}$ creatinine, with prednisolone treatment; inflammatory activity was also reduced considerably (table 2). Despite this decrease after prednisolone, the urinary nitrate excretion in patients with RA remained twice that in the control group $(p<0 \cdot 05)$. Urinary excretion of creatinine remained unchanged in patients with RA receiving prednisolone (table 3 ).

The values of urinary nitrate excretion did not correlate with values of CRP, ESR, joint count, or early morning stiffness.

\section{Discussion}

Our study demonstrated increased urinary excretion of nitrate in patients with RA. This finding is consistent with the results of Farrell et $a l,{ }^{17}$ who found increased serum

Table 3 Urine volume, urinary nitrate, and urinary creatinine excretion per day of patients with $R A$ before and two to four weeks after start of treatment with prednisolone $0.5 \mathrm{mg} / \mathrm{kg}$ body weight

\begin{tabular}{|c|c|c|c|c|c|c|c|c|}
\hline \multirow[t]{2}{*}{ Patient } & \multicolumn{2}{|c|}{ Urine volume (l) } & \multicolumn{2}{|c|}{ Urinary nitrate $(\mathrm{mmo} / \mathrm{l})$} & \multicolumn{2}{|c|}{ Urinary nitrate (mmol/day) } & \multicolumn{2}{|c|}{ Urinary creatinine (mmolday) } \\
\hline & Before & After & Before & After & Before & After & Before & After \\
\hline 1 & 0.75 & $0 \cdot 6$ & 1.48 & 1.69 & $1 \cdot 11$ & $1 \cdot 01$ & $7 \cdot 50$ & $7 \cdot 08$ \\
\hline 2 & $1 \cdot 5$ & 0.85 & 0.93 & $1 \cdot 25$ & $1 \cdot 39$ & 1.07 & $10 \cdot 80$ & $11 \cdot 22$ \\
\hline 3 & $1 \cdot 1$ & $1 \cdot 6$ & $1 \cdot 16$ & 0.54 & $1 \cdot 28$ & $0 \cdot 87$ & $9 \cdot 24$ & $11 \cdot 84$ \\
\hline 4 & $2 \cdot 3$ & $1 \cdot 8$ & 1.42 & 1.41 & $3 \cdot 26$ & $2 \cdot 53$ & $13 \cdot 02$ & $12 \cdot 56$ \\
\hline 5 & $2 \cdot 15$ & $2 \cdot 2$ & $0 \cdot 5$ & 0.37 & 1.09 & $0 \cdot 81$ & $7 \cdot 98$ & 8.56 \\
\hline 6 & $2 \cdot 1$ & $2 \cdot 0$ & 0.85 & 0.59 & $1 \cdot 78$ & $1 \cdot 19$ & $10 \cdot 58$ & $10 \cdot 26$ \\
\hline 7 & 1.55 & $2 \cdot 1$ & $2 \cdot 01$ & $1 \cdot 14$ & $3 \cdot 12$ & $2 \cdot 39$ & $7 \cdot 13$ & $6 \cdot 87$ \\
\hline 8 & $1 \cdot 7$ & 0.9 & $1 \cdot 61$ & 1.42 & $2 \cdot 73$ & $1 \cdot 27$ & $6 \cdot 31$ & $6 \cdot 84$ \\
\hline 9 & $1 \cdot 85$ & $1 \cdot 2$ & 1.02 & $1 \cdot 23$ & $1 \cdot 88$ & 1.47 & 6.55 & $6 \cdot 36$ \\
\hline 10 & 1.35 & $1 \cdot 25$ & 0.45 & 0.54 & $0 \cdot 61$ & $0 \cdot 67$ & $5 \cdot 97$ & $5 \cdot 30$ \\
\hline Mean (SD) & $1.64(0.49)$ & $1.45(0.57)$ & $1 \cdot 14(0.49)$ & $1.02(0.46)$ & $1.83(0.92)$ & $1.33(0.64)$ & $8.51(2.33)$ & $8 \cdot 69(2 \cdot 58)$ \\
\hline
\end{tabular}


concentrations of nitrite, indicating enhanced NO production, in serum and synovial fluid of patients with RA. The serum nitrite concentrations they measured reflected NO synthesis occurring at the time of blood sampling, because nitrite has a short serum half life; ${ }^{18}$ in contrast, nitrate excretion in urine over 24 hours is an index of daily NO synthesis. ${ }^{23}$ Despite these different approaches, the results of both studies are in agreement.

We found, in addition, that urinary nitrate excretion was reduced when systemic inflammatory activity, as indicated by CRP and ESR, was almost normalised by prednisolone treatment; interestingly, however, even those patients treated with prednisolone who achieved a return to normal values for laboratory parameters of inflammation retained a doubled urinary nitrate excretion compared with healthy volunteers. This may have reflected insufficient passage of time for normalisation of NO synthesis or, more probably, local production of $\mathrm{NO}$ in the remaining arthritic joints. The latter possibility is supported by the findings of Farrell et al in patients with osteoarthritis: those without systemic inflammatory activity had serum nitrite levels lower than those in patients with RA, but significantly higher than in healthy controls, probably as a result of local production of NO, as discussed by the authors. ${ }^{17}$

Further evidence for an involvement of the NO pathway in RA is given by the finding of increased nitrotyrosine concentrations in serum and synovial fluid from patients with $\mathrm{RA} ;{ }^{29}$ nitrotyrosine, a metabolite produced by NO dependent oxidative damage, ${ }^{30}$ was not detectable in sera from control subjects.

The most important potential biasing factor in the evaluation of NO synthesis by measurement of NO metabolites in body fluids is excess dietary intake of nitrite or nitrate. Our study groups were not subjected to a standardised diet, but excess dietary nitrite/nitrate intake was excluded. In the absence of intake in excess, dietary nitrite/nitrate contributes to urinary nitrate excretion to only a minor degree compared with endogenously generated nitrate. ${ }^{1921}$ The biasing effects of diet should therefore be insignificant, and the increased urinary nitrate excretion of our patients with RA may be assumed to indicate increased synthesis of NO. Two of the 18 control subjects also had high urinary nitrate excretions (271 and $164 \mu \mathrm{mol} / \mathrm{mmol}$ creatinine, respectively), but as they showed no recognisable differences compared with the other individuals in the control group (dietary nitrate/nitrite intake, health status, or drug treatment), they were included in the analysis.

Despite the clear evidence that NO plays a part in RA, the question remains whether NO is proinflammatory or anti-inflammatory. Current opinion is that large quantities of $\mathrm{NO}$ produced by the inducible NO synthase are cytotoxic and proinflammatory, whereas the low amounts of NO generated by the constitutive NO synthases are anti-inflammatory. ${ }^{31}$ Physiological amounts of NO produced by endothelial cells have been shown to reduce adhesion and emigration of granulocytes, ${ }^{32}$ and in a mouse model of hepatic damage, inhibition of NO synthesis increased liver injury, suggesting a protective role for $\mathrm{NO}$ in this model. ${ }^{33}$ In contrast, experiments in rats with adjuvant arthritis (a widely used animal model of $\mathrm{RA}$ ) suggested a proinflammatory role of NO: competitive inhibitors of NO synthase, such as $\mathrm{N}^{\mathrm{G}}$-nitro-L-arginine methyl ester or $\mathrm{N}^{\mathrm{G}}$-mono-methyl-L-arginine (L-NMA), suppressed the development of the disease and reduced its severity, respectively; concomitant treatment with $\mathrm{L}$-arginine, the substrate of $\mathrm{NO}$ synthase, abolished these effects. ${ }^{14} 3435$ Stefanovic-Racic et $a l^{35}$ determined urinary nitrate excretion, the parameter of interest in our study, in adjuvant arthritic rats; urinary nitrate excretion, which increased as the arthritis progressed, and disease activity were both inhibited by L-NMA in a dose dependent manner. In another animal model of arthritis, induced by intraperitoneal injection of streptococcal cell wall fragments in rats, administration of L-NMA profoundly reduced synovial inflammation, tissue damage, and NO production by synovial tissue. ${ }^{16}$

In the present study, treatment with prednisolone, which is known to inhibit induction of the inducible NO synthase, ${ }^{36}$ reduced urinary nitrate excretion in parallel with disease activity. This may be suggestive of proinflammatory properties of NO, though the wide pharmacological effects of prednisolone and the complexity of $\mathrm{NO}$ actions allow no definite conclusion. Further human studies with in vivo use of specific inhibitors of the inducible NO synthase are required to elucidate the pathophysiological role of $\mathrm{NO}$ inflammatory joint diseases.

The authors are grateful to Mrs I Fuchs for her excellent technical assistance.

1 Moncada S, Higgs A. The L-arginine-nitric oxide pathway. N Engl F Med 1993; 329: 2002-12.

2 Arend W P, Dayer J-M. Cytokines and cytokine inhibitors or antagonists in rheumatoid arthritis. Arthritis Rheum 1990; 33: 305-15.

3 Kilbourn R G, Belloni P. Endothelial cell production of nitrogen oxides in response to interferon gamma in combination with tumor necrosis factor, interleukin-1 or endotoxin. F Natl Cancer Inst 1990; 82: 772-6.

4 Hunt N C A, Goldin R D. Nitric oxide production by monocytes in alcoholic liver disease. 7 Hepatol 1992; 14: 146-50.

5 Moncada S. The L-arginine:nitric oxide pathway. Acta Physiol Scand 1992; 145: 201-27.

6 Palmer R M J, Hickery M S, Charles I G, Moncada S, Bayliss M T. Induction of nitric oxide synthase in human chondrocytes. Biochem Biophys Res Commun 1993; 193: 398-405.

7 Stefanovic-Racic M, Stadler J, Georgescu H I, Evans C H. Nitric oxide production by cytokine stimulated synovial fibroblasts. Trans Orthop Res Soc 1992; 17: 228.

8 Nathan C. Nitric oxide as a secretory product of mammalian cells. FASEB f 1992; 6: 3051-64.

9 Förstermann U, Closs E I, Pollock J S, Nakane M, Schwarz P, Gath I, Kleinert H. Nitric oxide isozymescharacterization, purification, molecular cloning, and characterization, purification, molecular
functions. Hypertension 1994; 23: 1121-31.

10 Palmer.R M J, Ferrige A G, Moncada S. Nitric oxide release accounts for the biological activity of endotheliumaccounts for the biological activity of endothe
derived relaxing factor. Nature 1987; 327: 524-6.

11 Radomski M, Palmer R M J, Moncada S. Comparative pharmacology of endothelium-derived relaxing factor, nitric oxide and prostacyclin in platelets. Br $\mathcal{J}$ Pharmaco 1987; 92: 181-7.

12 Garthwaite J, Charles S L, Chess-Williams R. Endotheliumderived relaxing factor release on activation of NMDA receptors suggests role as intercellular messenger in brain Nature 1988; 336: 385-8.

13 Ignarro LJ. Signal transduction mechanisms involving nitric oxide. Biochem Pharmacol 1991; 41: 485-90. 
14 Ialenti A, Moncada S, Di Rosa M. Modulation of adjuvant arthritis by endogenous nitric oxide. F Pharmacol 1993; 110: 701-6.

15 Stichtenoth D O, Gutzki F-M, Tsikas D, et al. Increased urinary nitrate excretion in rats with adjuvant arthritis. Ann Rheum Dis 1994; 53: 547-9.

16 McCartney-Francis N, Allen J B, Mizel D E, et al. Suppression of arthritis by an inhibitor of nitric oxide synthase. F Exp Med 1993; 178: 749-54.

17 Farrell A J, Blake D R, Palmer R M J, Moncada S. Increased concentrations of nitrite in synovial fluid and serum samples suggest increased nitric oxide synthesis in rheumatic diseases. Ann Rheum Dis 1992; 51: 1219-22.

18 Wennmalm A, Benthin G, Petersson A-S. Dependence of the metabolism of nitric oxide (NO) in healthy human whole blood on the oxygenation of its red cell haemoglobin. Br f Pharmacol 1992; 106: 507-8.

19 Green L C, Ruiz de Luzuriaga K, Wagner D A, et al. Nitrate biosynthesis in man. Proc Natl Acad Sci USA 1981; 78: 7764-8.

20 Radomski J L, Palmiri C, Hearn W L. Concentrations of nitrate in normal human urine and the effect of nitrate ingestion. Toxicol Appl Pharmacol 1978; 45: 63-8.

21 Bode-Böger S M, Böger R H, Creutzig A, et al. L-arginin infusion decreases peripheral arterial resistance and inhibits platelet aggregation in healthy subjects. Clin $\mathrm{Sc}$ 1994; 87: 303-10

22 Granger D L, Hibbs J B Jr, Broadnax L M. Urinary nitrate excretion in relation to murine macrophage activation. f Immunol 1991; 146: 1294-302.

23 Suzuki $H$, Ikenaga $H$, Hishikawa $K$, Nakaki $T$, Kato $R$ Saruta.$T$. Increases in $\mathrm{NO}_{2}^{-} \mathrm{NO}_{3}^{-}$excretion in the urine as an indicator of endothelium-derived relaxing factor during elevation of blood pressure. Clin Sci 1992; 82: during

24 Arnett F C, Edworthy S M, Bloch D A, et al. The American Rheumatism Association 1987 revised criteria for the classification of rheumatoid arthritis. Arthritis Rheum 1988; 31: 315-24

25 Selenka F, Brand-Grimm D. Nitrate and nitrite in human food: calculation of the daily intake and its range. Zentralbl Bakteriol [Orig B] 1976; 162: 449-66.
26 Rohmann U, Sontheimer H, eds. Nitratbelastung des Menschen durch Trinkwasser und andere Nahrungsmittel. Nitrat im Grundwasser. Karlsruhe: DVGW-Forschungstelle der Universität Karlsruhe, 1985; 253-6.

27 Gutzki F-M, Tsikas D, Alheid U, Frölich J C. Determination of endothelium derived nitrite/nitrate by gas chromatography/tandem mass spectrometry using gas chromatography/tandem mass spectrometry using
$\left({ }^{15} \mathrm{~N}\right) \mathrm{NaNO}_{2}$ as internal standard. Biol Mass Spectrom 1992; 21: $97-102$.

28 Fuchs H A, Brooks R H, Callahan L F, Pincus T. A simplified twenty-eight-joint quantitative articular index in rheumatoid arthritis. Arthritis Rheum 1989; 32:531-7.

29 Kaur H, Halliwell B. Evidence for nitric oxide-mediated oxidative damage in chronic inflammation-nitrotyrosine in serum and synovial fluid from rheumatoid patients. FEBS Lett 1994; 350: 9-12.

30 Van der Vliet A, O'Neill C A, Halliwell B, Cross C E, Kaur H. Aromatic hydroxylation and nitration of phenylalanine and tyrosine by peroxynitrite-evidence for hydroxyl radical production from peroxynitrite. FEBS hydroxyl radical product

31 Stefanovic-Racic M, Stadler J, Evans C H. Nitric oxide and arthritis. Arthritis Rheum 1993; 36: 1036-44

32 Kubes P, Suzuki M, Granger D N. Nitric oxide: an endogenous modulator of leukozyte adhesion. Proc Nat Acad Sci USA 1991; 88: 4651-5.

33 Biliar T R, Curran R D, Harbrecht B G, Stuehr D J, Demetris A J, Simmons R L. Modulation of nitrogen oxide synthesis in vivo: $\mathrm{N}^{\mathrm{G}}$-monomethyl-L-arginine inhibits endotoxin-induced nitrite/nitrate biosynthesis while promoting hepatic damage $\mathscr{f}$ Leukoc Biol 1990; 48. 565-9. involved in both initiation and development of adjuvant involved in both initiation and develop

35 Stefanovic-Racic M, Meyers K, Meschter C, Coffey J W, Hoffmann R A, Evans C H. N-monomethyl arginine, an inhibitor of nitric oxide synthase, suppresses the development of adjuvant arthritis in rats. Arthritis Rheum 1994; 37: 1062-9.

36 Di Rosa M, Radomski M, Carnuccio R, Moncada S. Glucocorticoids inhibit the induction of nitric oxide synthase in macrophages. Biochem Biophys Res Commun 1990; 172: 1246-52. 